\title{
Perencanaan Strategis Sektor Usaha Mikro Dalam Mengatasi Permasalahan Pemasaran \\ (Studi di Dinas Koperasi, Usaha Kecil Menengah, Perindustrian dan Perdagangan Kota Batu)
}

\author{
Dadan Sutrisno ${ }^{1}$, Agus Suryono ${ }^{2}$, Abdullah Said ${ }^{2}$ \\ ${ }^{1}$ Program Magister Ilmu Administrasi Publik, Fakultas IImu Administrasi, Universitas Brawijaya \\ ${ }^{2}$ Fakultas Ilmu Administrasi, Universitas Brawijaya
}

\begin{abstract}
Abstrak
Penelitian ini didasari oleh pentingnya peran usaha mikro dalam menjembatani sektor pertanian dan pariwisata di Kota Batu. Usaha mikro merupakan sektor unggulan demi peningkatan dan pemerataan kesejahteraan masyarakat. Akan tetapi, usaha mikro masih dihadapkan pada permasalahan pemasaran, dan memerlukan upaya dari pemerintah untuk mengatasinya, khususnya ditinjau dari aspek perencanaan strategis. Dengan demikian, tujuan dari penelitian ini adalah untuk: (1) menganalisis perencanaan strategis sektor usaha mikro; dan (2) merumuskan strategi dalam upaya mengatasi permasalahan pemasaran usaha mikro. Penelitian ini dilakukan dengan menggunakan pendekatan deskriptif kualitatif melalui alur interaktif pengumpulan data, kondensasi data, penyajian data dan penarikan kesimpulan. Selain itu, dilakukan analisis SWOT untuk merumuskan strategi berdasarkan potensi dan permasalahan yang teridentifikasi. Hasil penelitian menunjukkan bahwa: (1) proses penyusunan perencanaan strategis belum mencerminkan perencanaan yang efektif, dan dalam implementasinya terkendala ketidaksepahaman antar aktor perencana pada berbagai tingkatan organisasi; (2) pembinaan usaha mikro harus diarahkan pada strategi agresif yaitu ekspansi pasar dan penguatan daya saing dalam rangka mengadapi pasar bebas, melalui pembangunan jaringan kerjasama hulu-hilir dengan memberdayakan komunitas/asosiasi UMKM, dan fasilitasi pembangunan jaringan pemasaran online terpadu berbasis komunitas.
\end{abstract}

Kata kunci: perencanaan efektif, perencanaan strategis, usaha mikro

\begin{abstract}
This research is based on the importance of microbusiness in traversing agricultural and tourism in Batu. Microbusiness are the main sector for the improvement and the equalization of public welfare. However, microbusiness remain face marketing problems that calls government intervention. Therefore, this research aims: (1) to analyze the strategic planning in microbusiness; and (2) to formulate strategies to solve the marketing problems of microbusiness in Batu. This research was conducted with a descriptive and qualitative method by way of interactive data collection, data condensation, data display, and conclusion drawing. Besides, SWOT analysis is carried out to formulate the strategies from the identified problems and potentials. The research results show that: (1) the formulation of strategic planning does not reflect effective planning, and it's implementation is constrained by disagreement among planners in various organizational level; (2) microbusiness development should be directed to aggressive strategy, i.e. market expansion and competitiveness strengthening to face the free market, by means of establishing the network between the upstream and the downstream that involves MSME community/association, and facilitating the development of integrated and community-based online marketing network.
\end{abstract}

Keywords: effective planning, microbusiness, strategic planning

\section{PENDAHULUAN}

Usaha mikro, kecil dan menengah (UMKM) mempunyai peran yang besar dalam pembangunan ekonomi nasional dan dapat dipandang sebagai penyelamat dalam pemulihan ekonomi. Hal ini karena UMKM mampu untuk bertahan dan tumbuh dalam terpaan krisis sejak tahun 1998 [1]. Berdasarkan data yang dipublikasikan oleh Kementerian Koperasi dan Usaha Kecil Menengah (Kemenkop dan UKM), pada kurun waktu 2005 sampai dengan 2012, kontribusi UMKM mencapai 99,99 persen jika ditinjau dari sisi jumlah unit usaha. Sementara itu, dari sisi penyerapan tenaga kerja, berkisar antara 97,15 sampai dengan 97,30 persen [2]. Namun demikian, Utami dan Lantu (2014) dengan mengacu pada data Badan Perencanaan Pembangunan Nasional (Bappenas) juga menyatakan bahwa kontribusi UMKM hanya sepertiga dari total kontribusi seluruh unit usaha dalam menstimulasi pertumbuhan ekonomi

Alamat Korespondensi Penulis:

Dadan Sutrisno

Email : dantrisna@gmail.com

Alamat : Jl. MT. Haryono 163, Kota Malang, 65145 
nasional. Beberapa faktor penyebab rendahnya peran UMKM dalam mendukung pertumbuhan ekonomi adalah: (1) rendahnya kapasitas produksi; (2) rendahnya kualitas sumber daya manusia (SDM); (3) tingginya biaya pemasaran; dan (4) terbatasnya akses terhadap sumber daya produktif, seperti modal, sumber daya alam, informasi, pengetahuan, keahlian, dan teknologi [1].

Sebagaimana telah diamanatkan dalam Undang-Undang Nomor 20 Tahun 2008 tentang UMKM, Pemberdayaan UMKM memiliki tujuan mewujudkan pertumbuhan ekonomi, pemerataan dan peningkatan pendapatan rakyat, penciptaan lapangan kerja, dan penanggulangan kemiskinan. Sejalan dengan itu, World Bank (2001) memberikan petunjuk tentang prinsip dasar strategi pengembangan UMKM, yaitu: (1) menciptakan lapangan usaha; (2) menentukan kebijakan pengeluaran publik dengan memanfaatkan sumber daya publik secara efektif; (3) mendorong keterlibatan swasta dalam menyediakan layanan keuangan dan layanan lainnya [3]. Lebih lanjut, Kuncoro (2007) mengungkapkan strategi pemberdayaan UMKM yang telah diupayakan selama ini dapat diklasifikasikan dalam lima aspek utama, yaitu: (1) aspek manajerial, (2) aspek permodalan, (3) pengembangan program kemitraan dengan usaha besar, (4) pengembangan sentra industri kecil dalam suatu kawasan, (5) pembinaan untuk bidang usaha dan daerah tertentu [4].

Sejalan dengan semangat desentralisasi, maka peran pemerintah daerah benar-benar sangat diharapkan dalam mengatasi permasa-lahan yang dihadapi oleh usaha mikro. Beberapa pendapat terkait hal ini telah dikemukakan antara lain oleh Kadarisman (2007), yang menyatakan bahwa diperlukan komitmen dan keberpihakan pemerintah yang kuat dalam pembangunan ekonomi, yang tercermin dalam programprogram pembangunan, baik secara keseluruhan maupun sektoral untuk menggerakkan sektor perekonomian. Salah satu usaha yang relevan yang dapat dilakukan pemerintah adalah dengan memfasilitasi pertumbuhan koperasi dan UMKM [5].

Pesatnya perkembangan sektor pariwisata di Kota Batu berimbas pada menggeliatnya sektor UMKM khususnya skala usaha mikro sebagai pendukung kegiatan pariwisata. Akan tetapi, berdasarkan hasil assessment yang dilakukan Dinas Koperasi, UKM, Perindustrian dan Perdagangan (Dinas Koperindag) Kota Batu, usaha mikro di Kota Batu masih menghadapi berbagai permasalahan terutama pemasaran. Selain itu sebanyak 87,82 persen usaha mikro yang telah dilakukan assessment merupakan sektor industri pengolahan baik makanan dan minuman khas maupun kerajinan. Dengan demikian, maka faktor pemasaran menjadi semakin krusial, karena bagi industri pengolahan, sebaik apapun proses produksi maupun kualitas produk yang dihasilkan, jika tidak didukung dengan pemasaran yang baik maka akan menjadi sia-sia.

Sesuai dengan image Kota Batu yang dikenal sebagai kota pertanian dan pariwisata, dimana pertanian termasuk sektor primer dan pariwisata termasuk sektor tersier (jasa), maka pengembangan usaha mikro yang bergerak di bidang industri pengolahan (sektor sekunder) akan menggerakan sektor ekonomi di hulunya yaitu sektor pertanian dan sektor di hilirnya yaitu perdagangan serta jasa termasuk pariwisata. Dengan kata lain, pengembangan usaha mikro yang berbasis industri pengolahan dimana forward dan backward linkage yang dimiliki cukup besar, akan menciptakan daya ungkit yang besar bagi pertumbuhan ekonomi. Dengan mengembangkan usaha mikro, diharapkan peningkatan pertumbuhan ekonomi yang tercipta akan disertai pemerataan dan dapat dinikmati oleh masyarakat Kota Batu karena pelaku usaha mikro didominasi oleh masyarakat setempat.

Beberapa hasil penelitian yang telah dilakukan terkait dengan permasalahan UMKM juga menyatakan bahwa permasalahan pemasaran merupakan permasalahan krusial yang dihadapi oleh UMKM, salah satunya dikemukakan oleh Sok et al (2013) yang menyatakan bahwa faktor penentu keberhasilan UMKM adalah (1) kemampuan pemasaran; (2) kemampuan inovasi produk; dan (3) kemampuan untuk belajar dari keberhasilan maupun kegagalan di masa lalu [6]. Beberapa rekomendasi dalam mengatasi permasalahan tersebut juga dikemukakan oleh beberapa peneliti, antara lain McFarland dan McConnell (2012), Tambunan (2008), Triastuti (2013), Susilo (2010), serta Utami dan Lantu (2014). Meskipun memiliki perspektif yang berbeda-beda, pada dasarnya semuanya sepakat bahwa pemerintah memiliki peran yang vital dalam membantu pengembangan pemasaran UMKM [1][7][8][9] [10]. Lebih spesifik, peran terpenting yang harus diambil pemerintah adalah dengan menciptakan iklim usaha yang kondusif bagi UMKM [7][8], disamping itu kombinasi antara pemberian subsidi perizinan dan permodalan dengan fasilitasi sarana dan prasarana pemasaran merupakan intervensi kebijakan pemerintah yang 
baik dalam menstimulasi pengembangan UMKM [1][8][9]. Sedikit berbeda, Susilo (2010) lebih menekankan bahwa UMKM harus maju berkat passion-nya sendiri, sedangkan pemerintah berperan sebagai pendukung dan fasilitator hanya bagi UMKM yang benar-benar mau dan mampu untuk berkembang [10].

Terkait dengan pemasaran, Kotler et al (2010) mengemukakan bahwa ilmu pemasaran telah mengalami transformasi, yang secara garis besar dapat dibagi menjadi tiga era, yaitu: (1) era produc-centric atau marketing 1.0 ; (2) era customer-oriented atau marketing 2.0; dan (3) era value-driven atau marketing 3.0. Era Marketing 1.0 lahir pada era industri, dimana yang menjadi inti dari era ini adalah bagaimana produk dibuat untuk memenuhi permintaan massal sehingga dapat menekan biaya produksi dan dapat dijangkau oleh sebanyak-banyaknya konsumen. Era berikutnya adalah Marketing 2.0 yang masih berlangsung pada era teknologi informasi saat ini. Pada era ini penekanannya adalah setiap pelaku usaha harus menetapkan segmen pasar dan mengembangkan sebuah produk unggulan untuk target pasar tertentu. Namun era Marketing 2.0 ini memiliki kelemahan mendasar, yaitu menganggap konsumen sebagai target pasif. Berangkat dari kelemahan Marketing 2.0 inilah maka lahir era baru dari dunia pemasaran yang disebut era Marketing 3.0. Pada intinya Marketing 3.0 menganggap konsumen tidak hanya sekedar calon pembeli produk, melainkan memandang mereka sebagai manusia seutuhnya yang menginginkan dunia yang lebih baik. Dalam hal ini pelaku usaha diharapkan mampu menjadi salah satu solusi terhadap permasalahan di masyarakat [11]. Dari pemahaman ini, maka usaha mikro sudah sela-yaknya memandang penting strategi pemasaran agar produk yang dihasilkan dapat memiliki tempat di hati konsumen terlebih dalam menghadapi era pasar bebas.

Berbagai upaya telah dilakukan oleh pemerintah Kota Batu dalam mengatasi permasalahan yang dihadapi oleh UMKM khususnya usaha mikro. Namun demikian, masih ditemukan fakta bahwa masalah pemasaran masih menjadi keluhan utama pelaku usaha mikro. Selain itu, kegiatan pemasaran yang masih dilakukan secara pasif dengan menunggu datangnya wisatawan mengindikasikan bahwa upaya yang telah dilakukan Pemerintah Kota Batu, khususnya Dinas Koperindag belum berhasil dengan optimal. Hal tersebut diduga karena lemahnya perencanaan, khususnya perencanaan strategis. $\mathrm{Hal}$ ini sebagaimana dikemukakan oleh Suryono dan
Nugroho (2008), bahwa perencanaan strategis sangat penting karena memberikan kerangka dasar terhadap perencanaan lainnya dan merupakan titik awal dalam pemahaman dan penilaian kegiatan organisasi [12]. Selain itu, sebagaimana dikemukakan Salusu (2004), perencanaan strategis sangat penting dalam mengantisipasi ekonomi nasional dan global, serta semakin meluasnya ketidakpastian dan kompleksitas situasi lingkungan [13].

Konsep perencanaan strategis pada awalnya dikembangkan di sektor swasta, namun seiring dengan dinamika lingkungan yang terus berubah, pendekatan perencanaan strategis juga telah diadaptasi oleh organisasi publik dan nirlaba agar organisasi tersebut menjadi lebih efektif [14]. Prinsip umum perencanaan strategis sebagaimana dikemukakan oleh Riyadi dan Bratakusumah meliputi: (1) perencanaan strategis harus bersifat antisipatif terhadap berbagai permasalahan yang ada di masa depan dengan memperhatikan kondisi masa sekarang untuk mengatasinya; (2) perencanaan strategis harus berorientasi pada pencapaian hasil dengan visi, misi, tujuan, sasaran, dan strategi sebagai rel yang harus dijalankan secara konsisten; (3) perencanaan strategis harus menggambarkan apa yang diinginkan untuk dicapai dimasa depan oleh suatu organisasi ke arah peningkatan produktivitas dan kinerja; (4) perencanaan strategis harus memperhitungkan kemampuan internal dan kondisi eksternal; (5) harus ada komitmen dan konsensus untuk melaksanakannya secara konsisten sebagai hasil proses pengambilan keputusan bersama; (6) harus mencerminkan prioritas tindakan dalam upaya pencapaian hasil secara optimal; (7) perencanaan strategis dalam prosesnya harus mempertimbangkan input-input dari stakeholders atau kelompok sasaran; (8) harus memperhitungkan aspek keuangan untuk melaksanakannya; dan (9) harus dapat diukur hasilnya [15].

Bryson (2005) mengemukakan bahwa dalam proses perencanaan strategis terdapat berbagai tantangan yang dihadapi organisasi. Apabila tantangan tersebut dapat diatasi maka kemungkinan keberhasilan perencanaan strategis yang dilakukan akan semakin tinggi. Tantangan tersebut meliputi: (1) masalah manusia, yaitu berkaitan dengan manajemen perhatian dan komitmen dimana tidak semua individu dalam organisasi memahami dan menerima tahap-tahap strategis yang harus ditempuh organisasi; (2) masalah proses, yaitu manajemen ide strategis terkait dengan bagaimana siklus hidup dan 
bagaimana ide tersebut dikelola; (3) masalah struktural, berkaitan dengan bagaimana memperlakukan sifat perencanaan strategis yang kolektif dan bukan invidual; dan (4) masalah kelembagaan, permasalahan yang muncul mencakup transformasi lembaga dalam proses perencanaan strategis itu sendiri [14].

Pentingnya perencanaan strategis sendiri dapat ditinjau dari perkembangan teori perencanaan. Dalam perkembangannya, teori perencanaan itu sendiri tidak mampu untuk berdiri sendiri menjawab permasalahanpermasalahan yang tidak terduga tanpa kontribusi dari disiplin ilmu-ilmu lainnya. Masuknya substansi dari disiplin ilmu lain kedalam teori perncanaan inilah yang oleh Faludi (1973) disebut sebagai perencanaan substantif (theory in planning). Sementara itu teori perencanaan itu sendiri (theory of planning) oleh Faludi disebut sebagai perencanaan prosedural. Lebih lanjut Faludi (1973) menyatakan bahwa perencanaan yang baik adalah menggabungkan antara perencanaan substantif dan prosedural yang disebut dengan perencanaan efektif [16].

Berdasarkan uraian permasalahan lapangan dan kajian teoritis, maka tujuan penelitian ini dapat dirumuskan sebagai berikut: (1) menganalisis perencanaan strategis sektor usaha mikro di Kota Batu ditinjau dari proses penyusunan dan konsistensi dalam implementasinya kedalam rencana kerja tahunan; dan (2) merumuskan strategi dalam upaya mengatasi permasalahan pemasaran usaha mikro berdasarkan potensi dan permasalahan yang teridentifikasi.

\section{METODE PENELITIAN}

Penelitian ini menggunakan pendekatan kualitatif. Secara umum, menurut pemikiran para ahli diantaranya Denzin dan Lincoln (1994), Creswell (1998), Banister et al (1994) dan Moleong (2005), kesemuanya sebagaimana dikutip Herdiansyah (2011, h.7-9), memberikan pengertian yang relatif sama bahwa penelitian kualitatif memiliki ciri-ciri sebagai berikut: (1) kesatuan antara subjek penelitian dengan lingkungan sosialnya; (2) bersifat alamiah atau apa adanya; dan (3) interaksi atau keterlibatan peneliti yang mendalam dengan subjek yang diteliti [17]. Pada penelitian ini, pendekatan kualitatif dipilih karena penulis hendak memperoleh pemahaman yang mendalam tentang fenomena yang diteliti dan agar dapat menggali nilai yang terkandung dari perilaku partisipan. Hal ini sesuai dengan permasalahan penelitian yang telah penulis tetapkan. Selain itu, fleksibilitas dan keluwesan rancangan penelitian dari penelitian kualitatif juga menjadi alasan mengapa penulis memilih pendekatan kualitatif sehingga fakta beserta dinamika yang terjadi di situs penelitian dapat ditangkap dengan maksimal oleh peneliti. Untuk memperkuat hasil penelitian, pada penelitian ini ditambahkan teknik analisis SWOT (Strengths, Weaknesses, Opportunities dan Threats), sebagai alat analisis terhadap upaya Dinas Koperindag dan alat penyusunan strategi dalam mengatasi permasa-lahan pemasaran usaha mikro.

\section{Metode Pengumpulan Data}

Pengumpulan data dalam penelitian ini diperoleh melalui wawancara terhadap informan yang ditentukan berdasarkan kepakaran dan keterlibatan dalam pembinaan usaha mikro di Kota Batu yang meliputi unsur Tim Anggaran, Dinas Koperindag, Bappeda, PLUT-KUMKM, Asosiasi UMKM, Aktivis pemberdayaan masyarakat dan pelaku usaha mikro sendiri. Pengumpulan data juga dilakukan melalui observasi terhadap situasi yang terjadi di situs penelitian serta studi dokumentasi terhadap dokumen, peraturan perundang-undangan, artikel maupun sumber informasi lain yang relevan. Selain itu dilakukan juga pengumpulan data melalui kuesioner dalam rangka analisis SWOT. Responden analisis SWOT ditentukan secara purposive berdasarkan kepakaran dan keterlibatan dalam pembinaan usaha mikro di Kota Batu yang terdiri atas unsur Bidang UKM Dinas Koperindag, Pokja dan Konsultan PLUTKUMKM, Pengurus Asosiasi UMKM dan Pelaku usaha mikro.

Data yang diperoleh kemudian dianalisis dengan teknik analisis interaktif dari Miles, Huberman dan Saldana (2014) yang meliputi pengumpulan data, kondensasi data, penyajian data dan penarikan kesimpulan/verifikasi [18]. Data yang diperoleh melalui kuesioner dianalisis dengan metode analisis SWOT melalui pembobotan faktor-faktor internal dan faktorfaktor eksternal. Hasil pembobotan faktor digunakan untuk menentukan posisi strategis Dinas Koperindag dalam upaya mengatasi permasalahan pemasaran usaha mikro sehingga dapat disusun strategi dalam upaya mengatasi permasalahan pemasaran usaha mikro.

\section{HASIL DAN PEMBAHASAN}

\section{Perencanaan Strategis Sektor Usaha Mikro}

Proses penyusunan Rencana Strategis Satuan Kerja Perangkat Daerah (Renstra SKPD) telah diatur secara rinci dalam Peraturan Menteri 
Dalam Negeri (Permendagri) Nomor 54 Tahun 2010 Tentang Pelaksanaan Peraturan Pemerintah Nomor 8 Tahun 2008 Tentang Tahapan, Tatacara Penyusunan, Pengendalian, dan Evaluasi Pelaksanaan Rencana Pembangunan Daerah. Dalam proses penyusunan Renstra SKPD di Dinas Koperindag terdapat beberapa permasalahan yang tidak sesuai dengan Permendagri Nomor 54 Tahun 2010, antara lain tidak dibentuknya tim penyusun Renstra SKPD, dan tugas penyusunan Renstra SKPD dianggap melekat pada tugas dan fungsi Sub Bagian Program dan Pelaporan, sehingga tidak ada tim yang betul-betul bertanggungjawab atas terselenggaranya proses penyusunan dan penjaminan kualitas Renstra SKPD yang disusun. Allison dan Kaye (2005) secara tegas merekomendasikan untuk dibentuk sebuah tim/panitia perencana yang akan melaksanakan proses perencanaan strategis. Panitia perencana strategis yang dibentuk oleh pimpinan bukan semata-mata bertanggungjawab melakukan tahap-tahap perencanaan strategis, tetapi lebih kepada bertanggungjawab bahwa proses perencanaan strategis terlaksana [19].

Permasalahan lainnya adalah minimnya keterlibatan dan input dari sasaran pelayanan SKPD dalam hal ini UMKM di dalam proses perencanaan, sehingga program yang disusun hanya berdasarkan perspektif SKPD. Allison dan Kaye (2005) menyatakan ada empat konsep utama yang menentukan keberhasilan suatu perencanaan strategis, dimana satu diantaranya adalah membangun komitmen bersama antar stakeholder utama secara sitematis termasuk klien dan masyarakat [19]. Hal senada juga dikemukakan oleh Riyadi dan Bratakusumah (2004) yang menyebutkan salah satu prinsip umum perencanaan strategis adalah dalam prosesnya harus mempertimbangkan input-input dari stakeholders atau kelompok sasaran [15]. Lebih lanjut, Faludi (1973) menekankan bahwa feedback dalam perencanaan, baik itu dalam tahap formulasi maupun implementasi merupakan hal yang penting. Ketika institusi perencana bersentuhan dengan kepentingan masyarakat, maka hal ini lebih penting lagi, karena bagaimanapun, gambaran yang dimiliki oleh perencana atas permasalahan masyarakat yang dilayaninya tidaklah benar-benar gamblang [16]. Untuk itu, feedback dari masyarakat menjadi sangat penting di dalam proses perencanaan yang dilakukan oleh pemerintah.

Permasalahan selanjutnya adalah dokumen Renstra SKPD yang telah selesai disusun tidak disahkan melalui Keputusan Kepala Daerah sehingga aspek legalnya menjadi lemah. Terkait hal ini, Bryson (2005) menegaskan bahwa Renstra harus menjadi pedoman bagi organisasi. Dengan legalitas yang lemah, maka fungsi Renstra sebagai pedoman pun akan menjadi lemah [14].

Renstra SKPD sebagai dokumen perencanaan jangka menengah SKPD, dalam pelaksanaannya dijabarkan dalam dokumen perencanaan tahunan, yaitu Rencana Kerja SKPD (Renja SKPD). Untuk mengetahui sejauh mana Renstra SKPD diimplementasikan, dapat dilihat dari konsistensi antara Renstra SKPD dengan Renja SKPD. Terdapat dua aspek yang dilihat dalam menganalisis konsistensi dalam implementasi Renstra SKPD, yaitu aspek kinerja dan aspek keuangan. Aspek kinerja melihat konsistensi target kinerja pada Renstra SKPD, Renja SKPD, Dokumen Pelaksanaan Anggaran/Dokumen Pelaksanaan Perubahan Anggaran (DPA/DPPA) dan realisasi kinerja. Sementara aspek keuangan melihat konsistensi anggaran pada Renstra SKPD, Renja SKPD, DPA/DPPA dan realisasi keuangan.

Hasil penelitian menunjukkan bahwa dalam implementasi Renstra Dinas Koperindag pada tahun anggaran 2013 dan 2014 terdapat beberapa inkonsistensi, antara lain kegiatan yang telah diamanatkan di Renstra SKPD tidak diakomodasi di Renja SKPD dan sebaliknya. Terdapat pula kegiatan yang telah diakomodasi di Renja SKPD tetapi tidak dianggarkan dalam DPA/DPPA. Berdasarkan hasil wawancara dan dokumentasi, diketahui bahwa faktor utama yang menyebabkan terjadinya inkonsistensi adalah tidak adanya kesepahaman antar aktor yang terlibat dalam proses perencanaan pada berbagai tingkatan organisasi. Mengacu pada pendapat Bryson (2005), permasalahan tersebut cenderung termasuk ke dalam faktor struktural dan faktor kelembagaan. Dalam hal ini, faktor struktural terindikasi dari lemahnya koordinasi, baik internal Dinas Koperindag, maupun pada perencanaan tingkat kota. Sementara itu faktor kelembagaan diindikasikan dengan terjadinya penyusunan kegiatan yang mengikuti anggaran tahunan, dan bukan anggaran yang disesuaikan mengikuti kegiatan yang sudah direncanakan. Adanya ketidakselarasan antara perencanaan jangka menengah dalam Renstra SKPD dengan perencanaan tahunan dalam Renja SKPD yang disebabkan tidak adanya konsensus antar perencana pada berbagai tingkatan organisasi membuktikan permasalahan dalam perencanaan sebagaimana yang Faludi (1973) sebutkan sebagai permasalahan pemahaman perencana [16]. Menurut Faludi (1973), permasalahan 
pemahaman perencana disebabkan oleh pemahaman dan konstruksi berpikir dari masingmasing perencana yang berbeda antara satu dengan yang lain [10]. Kondisi tersebut jelas tidak sesuai dengan prinsip perencanaan strategis sebagaimana diungkapkan Riyadi dan Bratakusumah (2004) yang menyatakan bahwa salah satu prinsip dari perencanaan strategis adalah harus ada komitmen dan konsensus untuk melaksanakannya secara konsisten sebagai hasil proses pengambilan keputusan bersama [15].

Lebih lanjut menurut Hausler (1969) sebagaimana dikutip Faludi (1973 h.224), pengambilan keputusan dalam perencanaan dapat dilakukan melalui tiga cara, yaitu (1) berdasarkan otoritas seorang aktor (otoritatif); (2) melalui perhitungan matang dari beragam pilihan yang ada dan disepakati bersama (kalkulatif), dan (3) gabungan dari keduanya. Secara umum pengambilan keputusan dalam perencanaan merupakan kombinasi antara keputusan otoritatif dan kalkulatif [16]. Semakin tinggi level organisasi dalam pemerintahan daerah semakin besar pengaruh pendekatan otoritatif yang diambil. Hasil penelitian menunjukkan bahwa meskipun perencana pada tataran SKPD teknis termasuk Dinas Koperindag sudah menyusun perencanaan jangka menengah untuk periode lima tahun termasuk perencanaan untuk setiap tahunnya, akan tetapi selalu mentah kembali ketika dibahas pada tataran yang lebih tinggi. Hal tersebut merupakan dampak dari dominannya pengambilan keputusan otoritatif. Dengan demikian keberlanjutan suatu program menjadi tidak dapat berjalan karena setiap tahun hanya ada dua kemungkinan yang terjadi dalam pelaksanaan program, yaitu (1) program rutin yang berlangsung setiap tahun yang merupakan amanat dari tugas dan fungsi organisasi tanpa adanya evaluasi yang memadai mengenai outcome dari program tersebut; (2) program insidental tanpa perencanaan yang matang yang merupakan hasil dari pengambilan keputusan otoritatif yang tingkat prioritasnya tidak melalui kesepakatan bersama.

\section{Strategi Dalam Upaya Mengatasi Permasalahan Pemasaran Usaha Mikro}

Untuk dapat menyusun strategi dalam upaya mengatasi permasalahan pemasaran usaha mikro diperlukan identifikasi terhadap potensi dan permasalahan yang ada. Dalam mengimplementasikan Renstra SKPD, Dinas Koperindag dihadapkan pada berbagai kondisi yang dapat menjadi potensi maupun permasalahan. Berdasarkan hasil wawancara dan observasi, kondisi yang menjadi potensi dalam upaya mengatasi permasalahan pemasaran usaha mikro meliputi: (1) besarnya peluang pasar sebagai dampak positif dari perkembangan pariwisata di Kota Batu; (2) berkembangnya model pemasaran secara online sebagai akibat dari semakin familiarnya konsumen terhadap transaksi $e$ commerce, dan terbukti banyak usaha mikro yang terbantu dengan adanya peluang tersebut; (3) banyaknya dukungan program dan anggaran dari pemerintah, baik pemerintah pusat maupun daerah terhadap pengembangan usaha mikro di daerah. Ditinjau dari sisi Dinas Koperindag, hal ini membantu dalam upaya mengimplementasikan program dan kegiatan; (4) adanya PLUT-KUMKM sebagai unit dari Dinas Koperindag yang fokus membina dan mengembangkan UMKM; (5) karakteristik wilayah Kota Batu yang memiliki ketersediaan bahan baku lokal yang memadai; (6) usaha mikro cenderung bersifat padat karya dan mampu memberdayakan masyarakat sekitar; dan (7) adanya sinergi yang baik antara Dinas Koperindag dengan asosiasi/komunitas UMKM.

Sementara itu kondisi yang menjadi permasalahan meliputi: (1) permasalahan SDM, yaitu usaha mikro cenderung kesulitan menangkap peluang karena keterbatasan SDM/semua dikerjakan sendiri, di sisi lain ketika akan mencari tenaga kerja, mereka kesulitan untuk memperoleh SDM berkualitas yang loyal; (2) belum adanya data UMKM yang komprehensif dalam rangka pelaksanaan pembinaan usaha mikro yang tepat sasaran; (3) usaha mikro cenderung belum melakukan manajemen dan pencatatan keuangan yang memadai sehingga sulit untuk dinilai kelayakan usahanya terutama dalam rangka mengakses permodalan; (4) usaha mikro cenderung belum memiliki tempat yang representatif untuk proses produksi; (5) usaha mikro cenderung masih lemah dalam inovasi pemasaran dan branding; (6) masuknya produk sejenis dari luar Kota Batu, terlebih setelah diterapkannya pasar bebas ASEAN; (7) adanya oknum penjual produk repackage ilegal dan ancaman kanibalisme dari oknum usaha bermodal besar.

Berdasarkan hasil identifikasi potensi dan permasalahan, dapat disusun strategi dalam upaya mengatasi permasalahan pemasaran usaha mikro dengan mengelompokkan potensi dan permasalahan ke dalam faktor internal yang meliputi kekuatan dan kelemahan, serta faktor eksternal yang meliputi peluang dan ancaman. Setelah dikelompokkan, faktor-faktor tersebut kemudian diberi bobot berdasarkan pendapat 
responden. Dalam rangka merumuskan strategi dan memilih strategi prioritas, maka hasil pembobotan Internal Strategic Factor Analysis Summary (IFAS) dan External Strategic Factor Analysis Summary (EFAS) diplot kedalam kuadran matriks Grand Strategy untuk menentukan peta strategis. Strategi untuk masing-masing kuadran diperoleh dari interaksi antara IFAS dan EFAS. Dengan demikian akan dihasilkan alternatif strategi, yaitu strategi Strength-Opportunity (SO), strategi Weakness-Opportunity (WO), strategi Strength-Threat (ST), dan strategi WeaknessThreat (WT) untuk kemudian dipilih berdasarkan kuadaran yang diperoleh dari plot hasil pembobotan.

Berdasarkan hasil pembobotan, strategi yang dipilih adalah strategi pada kuadran I, yaitu strategi Strength-Opportunity (SO) yang dapat diartikan sebagai strategi yang menggunakan kekuatan untuk merebut peluang. Posisi ini merupakan posisi yang sangat menguntungkan, karena dalam upaya mengatasi permasalahan pemasaran usaha mikro, Dinas Koperindag dalam hal ini memiliki kekuatan yang lebih besar dari kelemahan dan dihadapkan pada peluang yang lebih besar daripada ancaman. Kondisi tersebut dapat diartikan bahwa meskipun Dinas Koperindag menghadapi kendala berupa tidak adanya data UMKM yang komprehensif dan akurat, tetapi pembinaan terhadap UMKM khususnya usaha mikro masih dapat berjalan optimal dengan adanya PLUT-KUMKM dan sinergi yang baik dengan komunitas/asosiasi UMKM. Selain itu, adanya dukungan program dan anggaran baik dari pemerintah pusat maupun provinsi juga dapat menutupi kelemahan tersebut. Sementara itu jika ditinjau dari sudut pandang usaha mikro yang merupakan sasaran dari pelayanan Dinas Koperindag, kondisi tersebut dapat diartikan bahwa meskipun usaha mikro memiliki kelemahan dalam hal manajemen usaha, sarana dan prasarana produksi, kesulitan memperoleh tenaga kerja yang kompeten dan loyal, serta inovasi dalam pemasaran dan branding, masih dapat tertutupi dengan kondisi Kota Batu dimana bahan baku lokal masih tersedia serta kemampuan dari usaha mikro yang sanggup memberdayakan masyarakan sekitar. Selain itu, kondisi yang dianggap ancaman berupa masuknya produk dari luar baik saat ini terlebih setelah pasar bebas ASEAN diberlakukan dan ancaman oknum yang mengkanibal pasar masih teratasi dengan adanya potensi pasar yang besar sebagai dampak positif pariwisata dan berkembangnya model pemasaran secara online.
Hasil analisis menunjukkan bahwa posisi strategis pembinaan usaha mikro di Kota Batu berada pada posisi yang mendukung strategi agresif. Dengan demikian, dalam menghadapi Masyarakat Ekonomi ASEAN (MEA), Pemerintah Kota Batu dalam hal ini Dinas Koperindag dapat mulai memperlakukan usaha mikro sebagai entitas ekonomi yang fokus pembinaannya bukan pada aspek permodalan lagi tetapi pada penguatan daya saing dan ekspansi pasar serta pemberian dorongan untuk berinovasi. Dalam era perdagangan bebas, salah satunya melalui implementasi MEA, standarisasi dan sertifikasi merupakan hal yang krusial dalam mendukung daya saing. Standar kualitas produk, proses produksi, perlindungan hak kekayaan intelektual dan perubahan mindset SDM ke arah yang lebih baik merupakan hal yang harus diprioritaskan disamping ekspansi pasar.

Strategi yang dapat diterapkan berdasarkan hasil analisis posisi strategis meliputi: (A) Pembangunan jaringan kerjasama hulu-hilir dengan memberdayakan komunitas/asosiasi UMKM. Melihat peta usaha mikro di Kota Batu yang didominasi oleh industri pengolahan, baik berupa pengolahan makanan dan minuman maupun kerajinan, maka dalam sistem pembinaannya perlu memperhatikan tiga sub sistem di dalamnya, yaitu sub sistem hulu, sub sistem proses, dan sub sistem hilir. Yang dimaksud dengan hulu dalam hal ini terkait dengan bahan baku yang diperlukan oleh industri tersebut. Sementara itu yang dimaksud dengan hilir adalah terkait dengan proses distribusi dan pemasaran dari produk yang dihasilkan.

Pada sub sistem hulu, perlu diperhatikan persoalan ketersediaan bahan baku. Dari hasil penelitian diketahui bahwa pada saat ini bahan baku yang diperlukan oleh usaha mikro masih mencukupi dari pertanian lokal, akan tetapi belum ada kajian yang meneliti keberlanjutan dari ketersediaan bahan baku lokal tersebut. Dengan sektor pertanian yang dominan, Kota Batu seharusnya mulai memikirkan kemampuan sektor pertanian lokal untuk memenuhi kebutuhan usaha mikro. Kota Batu yang masih bagian dari wilayah Malang Raya juga berlokasi tidak jauh dari perguruan tinggi besar yang ada di Kota Malang. Dengan demikian, Pemerintah Kota Batu dapat bekerjasama dengan perguruan tinggi untuk mengkaji keberlanjutan dari ketersediaan bahan baku untuk usaha mikro.

Penggunaan bahan baku lokal merupakan hal yang sangat penting untuk dipertahankan karena akan menguntungkan baik bagi usaha mikro 
maupun bagi para petani. Bagi usaha mikro, penggunaan bahan baku lokal membuat beban biaya produksi menjadi minimal karena tidak perlu mengeluarkan biaya transportasi yang besar untuk memperoleh bahan baku. Bagi para petani, keuntungan yang diperoleh adalah kepastian adanya pembeli serta biaya pengiriman yang lebih murah. Dengan terjalinnya jaringan kerjasama penyediaan bahan baku diharapkan terjadi kestabilan harga yang selama ini merugikan para petani, dimana ketika panen raya harga produk pertanian sering jatuh karena permainan tengkulak. Penggunaan bahan baku lokal untuk industri khususnya yang dilakukan oleh usaha mikro akan mendorong pembangunan ekonomi menuju kemandirian daerah. Arsyad (2004) mengemukakan permasa-lahan pokok dalam pembangunan daerah terletak pada penekanan kebijakan-kebijakan pembangunan yang didasarkan pada kekhasan daerah yang bersangkutan (endogenous development) [20]. Demikian halnya Kuncoro (2012) menekankan bahwa dalam pembangunan ekonomi dalam rangka meningkatkan pertum-buhan ekonomi, menciptakan lapangan kerja, meningkatkan taraf hidup dan mengentaskan kemiskinan haruslah berbasis kepada potensi lokal [21].

Dengan melihat empat peran pemerintah daerah dalam pembangunan ekonomi daerah, yaitu sebagai enterpreneur, koordinator, fasilitator dan stimulator [21], maka dalam rangka membanguna jaringan kerjasama antara sektor pertanian sebagai penyedia bahan baku dan sektor usaha mikro, pemerintah daerah dapat mengambil peran sebagai koordinator dan fasilitator. Pemerintah daerah dapat mengkoordinasikan dan memberdayakan komunitas/ asosiasi UMKM yang ada untuk menjalin kerjasama yang saling menguntungkan dengan kelompok-kelompok pertanian.

Strategi yang diterapkan dalam sub sistem proses adalah melalui peningkatan kualitas produksi, SDM dan manajemen usaha mikro. Pada sub sistem proses, strategi lain dalam matriks interaksi IFAS-EFAS tidak dapat dikesampingkan. Dalam rangka memperbaiki proses produksi otomatis akan memperbaiki SDM dan manajemen yang ada. Permasalahan yang ditemukan seperti sarana dan prasarana produksi yang belum standar memerlukan peran pemerintah untuk memberikan fasilitasi misalnya sertifikasi halal, pendaftaran merek, dan sertifikasi industri seperti Hazard Analysis Critical Control Point (HACCP), Good Manufacturing Practice (GMP) dan ISO.

Sementara itu dari sisi SDM, hasil penelitian menunjukkan bahwa sebagian besar mindset pelaku usaha mikro belum memikirkan pentingnya administrasi keuangan dan perluasan pemasaran. Oleh karena itu, pemerintah perlu membina SDM usaha mikro untuk mengubah mindset mereka agar lebih terbuka terhadap perkembangan perekonomian dan teknologi. Selain itu penting untuk diberikan pemahaman bahwa seiring dengan diimplementasikannya pasar bebas, maka standarisasi dan sertifikasi produk dan proses produksi menjadi sangat penting.

Pada sub sistem hilir, jaringan kerjasama yang dibangun adalah kerjasama pemasaran produk usaha mikro dengan entitas yang berpotensi sebagai pasar dari produk usaha mikro seperti pengelola objek wisata baik di dalam maupun luar Kota Batu, gerai atau outlet penyedia oleh-oleh baik yang ada di Kota Batu maupun di luar Kota Batu. Berdasarkan hasil penelitian, permasalahan yang terjadi adalah lemahnya posisi tawar usaha mikro terhadap pengelola objek wisata maupun outlet oleh-oleh sehingga usaha mikro kurang diuntungkan dengan bentuk kerjasama ini. Untuk mengatasi persoalan tersebut diperlukan kerjasama semua stakeholder baik dari unsur pemerintah, komunitas/asosiasi UMKM dan para pengusaha objek wisata dan outlet oleh-oleh. Pemerintah dapat bekerjasama dengan pengusaha objek wisata dan hotel agar menjual produk usaha mikro dengan kriteria dan standar yang sesuai dan dapat dipenuhi, serta menguntungkan bagi usaha mikro. Pemerintah bersama komunitas/ asosiasi UMKM berkolaborasi untuk terus membangun kesadaran dan memfasilitasi usaha mikro untuk meningkatkan kualitas produknya. Di sisi lain pemerintah harus memperkuat kelembagaan komunitas/ asosiasi usaha mikro agar memiliki posisi tawar yang kuat dalam kerjasama pemasaran produk usaha mikro. Secara skematis, strategi membangun jaringan kerjasama hulu-hilir dengan memberdayakan komunitas/asosiasi UMKM dapat dilihat pada Gambar 1. 


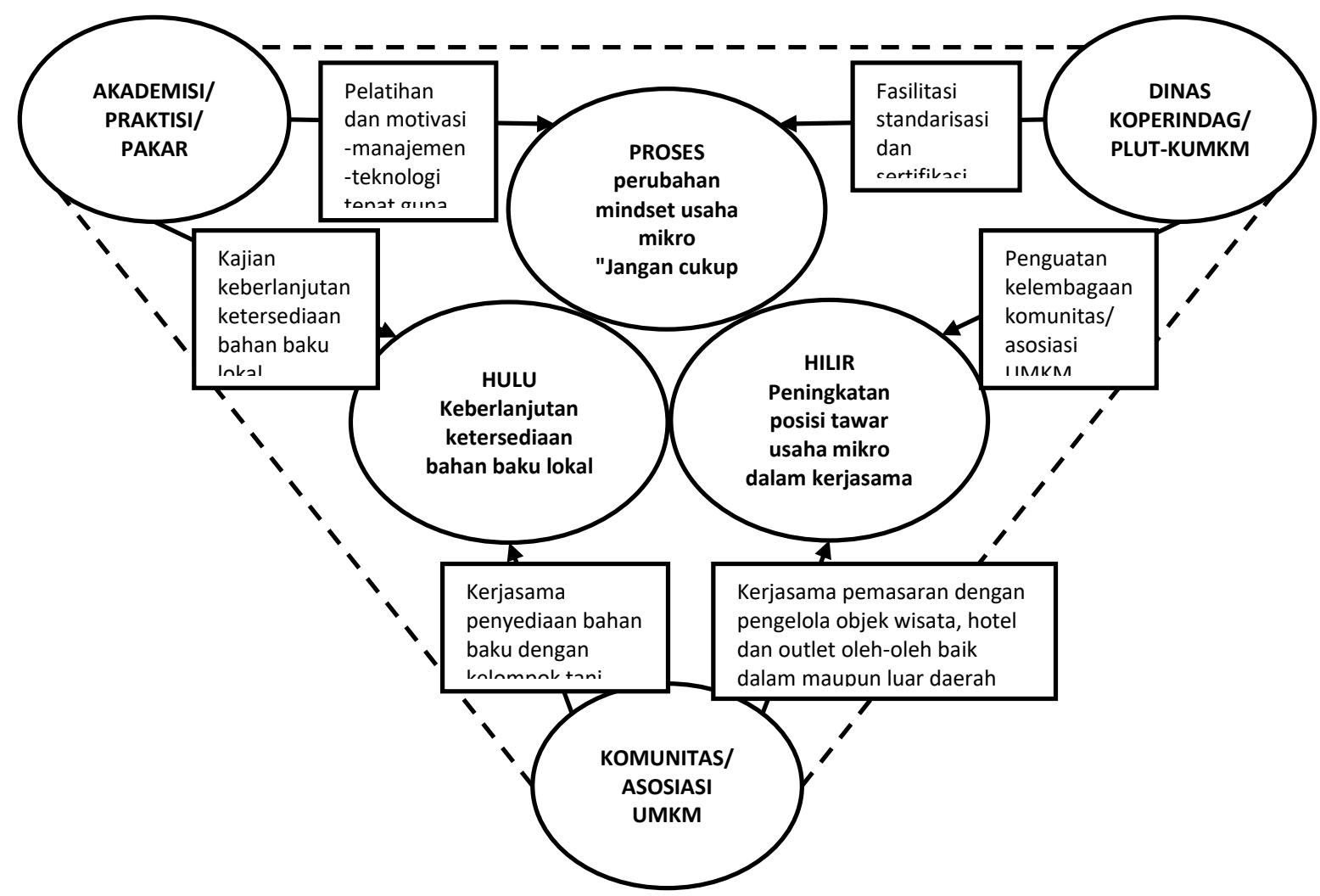

Sumber: Hasil penelitian

Gambar 1. Strategi Pembangunan Jaringan Kerjasama Hulu-Hilir Dengan Memberdayakan Komunitas/Asosiasi UMKM.

(B) Fasilitasi pembangunan jaringan pemasaran online terpadu berbasis komunitas. Karakteristik masyarakat khususnya generasi muda saat ini merupakan peluang yang besar bagi usaha mikro, terlebih dengan semakin derasnya penetrasi teknologi khususnya smartphone dimana saat ini telah menjadi kebutuhan yang dianggap sangat penting. Keuntungan menggunakan pemasaran online dapat dilihat dari empat perspektif, yaitu perspektif finansial, perspektif hubungan, perspektif perniagaan, dan perspektif respon-sivitas. Penjelasan masingmasing perspektif tersebut adalah: (1) perspektif finansial, menekankan pada pemasaran online lebih merupakan entitas elektronik daripada entitas fisik sehingga dapat mereduksi biaya pemasaran dan meningkatkan efisiensi; (2) perspektif hubungan, dimana pada pemasaran online dapat tercipta hubungan baru, pasar baru dan meningkatkan interaksi baik dengan pelanggan, pemasok, distributor maupun mitra bisnis lainnya; (3) perspektif perniagaan, lebih menekankan pada efektivitas proses penjualan dengan menggunakan pemasaran online; (4) perspektif responsivitas, berkaitan dengan mengurangi waktu yang dibutuhkan antara permintaan bisnis dan pemenuhannya. Dampak yang diharapkan melalui pemasaran online adalah meningkatnya efisiensi, menekan tingkat kesalahan dan meningkatkan kepuasan pelanggan [22].

Semakin familiarnya masyarakat terhadap pemasaran online dan pengalaman beberapa pelaku usaha mikro yang sukses dalam pemasaran online memberikan peluang dalam pengembangan usaha mikro. Dengan adanya komunitas UMKM yang proaktif dan bersinergi dengan Dinas Koperindag dalam mengembangkan usaha mikro telah menjadi hal yang positif dengan membuat suatu portal terpadu yang berisi katalog produk dan profil usaha mikro di Kota Batu. Portal ini hanya sebagai media promosi terpadu untuk memudahkan pembeli dalam mencari produk yang diinginkan. Nantinya portal ini dikelola oleh komunitas sedangkan pemerintah dapat membantu dalam penyediaan dan pembuatan portalnya.

Di Kota Batu, dengan kemajuan sektor pariwisata, serta didukung semangat asosiasi dan pelaku UMKM menjadikan pembuatan portal tersebut potensi yang layak dikembangkan, mengingat promosi melalui media online tidak terbatas wilayah sehingga mampu meraih pangsa pasar yang lebih luas. Dengan dikelola oleh 
komunitas/asosiasi UMKM, diharapkan UMKM khususnya usaha mikro akan lebih merasa memiliki dan aktif terlibat dalam pengembangan kedepannya. Dengan dibangun sebuah portal terpadu yang diintegrasikan dengan promosi wisata dan kebudayaan diharapkan akan terbangun sinergi positif antara pengembangan pariwisata, nilai budaya dan UMKM khususnya usaha mikro. Selain itu dengan konsep marketing 3.0 dari Kotler et al, (2010) yang menganggap konsumen tidak hanya sekedar calon pembeli produk, melainkan memandang mereka sebagai manusia seutuhnya yang menginginkan dunia yang lebih baik, maka dalam hal ini produk usaha mikro diharapkan tidak hanya sebagai oleh-oleh atau jajanan, melainkan menjadi produk yang mampu bercerita tentang budaya dan sejarah yang ada di Kota Batu dan mendukung kelestarian budaya dan lingkungan [11]. Oleh karena itu dalam pengembangan portal pemasaran produk usaha mikro perlu diintegrasikan dengan nilai-nilai budaya yang ada di masyarakat Kota Batu. Skema portal produk usaha mikro dapat dilihat pada Gambar 2.

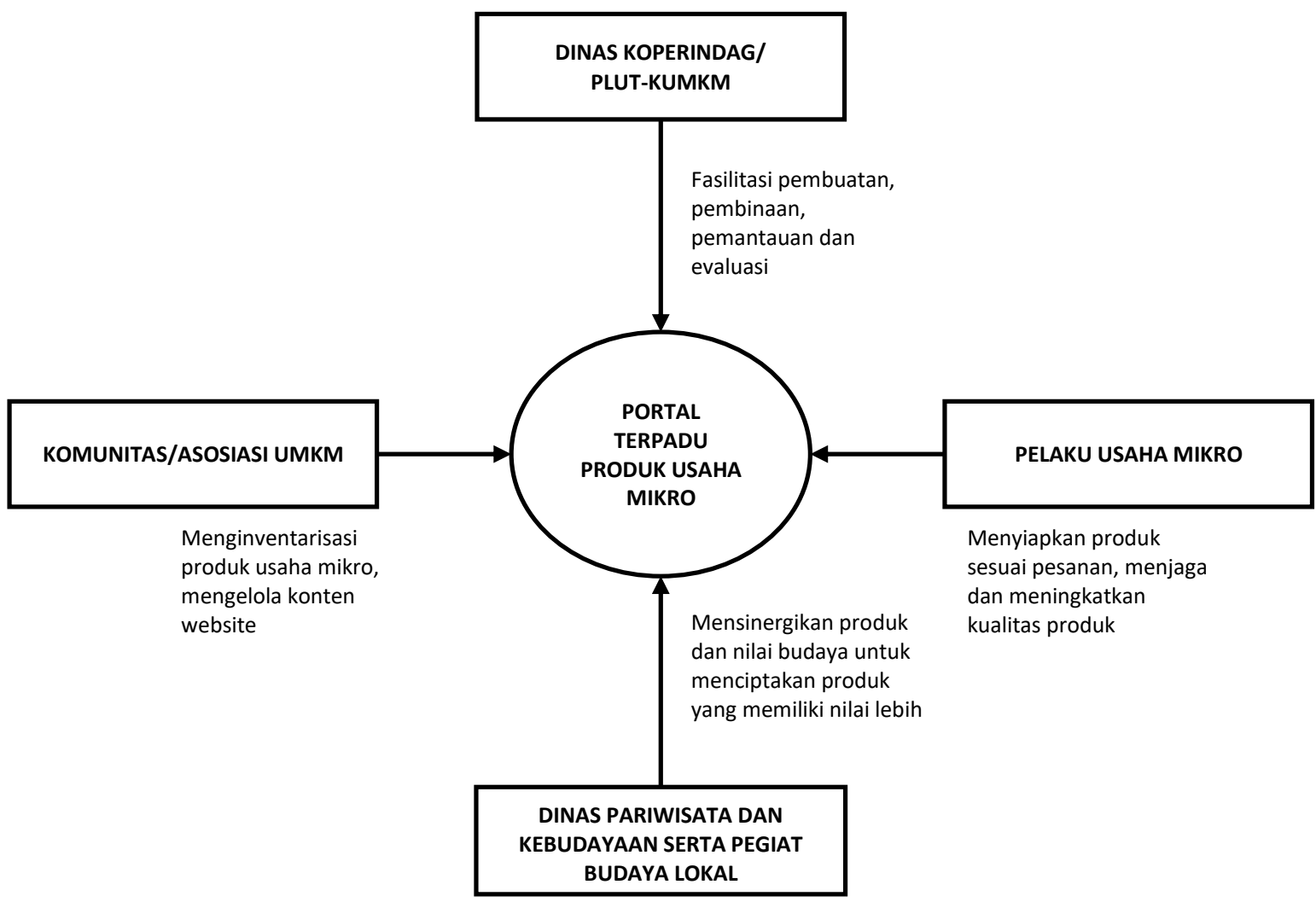

Sumber: Hasil penelitian

Gambar 2. Strategi Fasilitasi Pembangunan Jaringan Pemasaran Online Terpadu Berbasis Komunitas

Jika meninjau strategi pembangunan sektor UMKM sebagaimana tercantum dalam RPJMD yaitu: (1) melakukan pembinaan terhadap UKM yang telah ada dalam masyarakat; (2) memfasilitasi UKM dalam hal sarana, permodalan, dan pemasaran; (3) menyelenggarakan pelatihan terhadap para pelaku UKM terkait dengan berbagai pengetahuan pengembangan usaha; (4) memfasilitasi UKM dengan penerapan teknologi tepat guna; (5) memfasilitasi berbagai upaya kerjasama dan kemitraan usaha; dan (6) memfasilitasi upaya perlindungan hukum terhadap hasil produksi UKM, yang kemudian diturunkan dalam Renstra Dinas Koperindag menjadi (1) penyelenggaran dan partisipasi dalam pameran produk UMKM, (2) memperluas kerjasama dan jaringan pemasaran produk, (3) meningkatkan mutu produk, (4) memperbaiki sistem distribusi produk, dan (5) merevitalisasi sarana dan prasarana pemasaran lokal, maka strategi yang dihasilkan dari penelitian ini merupakan strategi yang melengkapi, mengintegrasikan dan mengoperasionalkan strategistrategi yang telah tercantum dalam dokumen perencanaan tersebut. Dengan melihat persoalan utama dalam implementasi Renstra SKPD adalah inkonsistensi pada aspek penganggaran, maka yang dibutuhkan adalah komitmen yang kuat 
untuk mengimplementasikan Renstra SKPD maupun dokumen perencanaan lainnya secara konsisten.

\section{KESIMPULAN DAN SARAN \\ Kesimpulan}

Berdasarkan hasil penelitian dan pembahasan, maka dapat ditarik kesimpulan bahwa perencanaan strategis yang dilakukan Dinas Koperindag dalam penyusunannya cenderung didominasi perencanaan prosedural dan mengabaikan aspek perencanaan substantif, sehingga belum mencerminkan perencanaan yang efektif. Sementara itu kendala terbesar dalam implementasi Renstra ke dalam Renja adalah ketidaksepahaman antar aktor perencana pada berbagai tingkatan organisasi, dimana semakin tinggi tingkatan organisasi maka porsi pengambilan keputusan yang bersifat otoritatif semakin besar dibandingkan yang bersifat kalkulatif. Hal tersebut mendukung teori perencanaan Faludi bahwa untuk menghasilkan perencanaan yang efektif diperlukan perpaduan antara pendekatan perencanaan prosedural dan perencanaan substantif.

Posisi strategis Dinas Koperindag dalam pembinaan usaha mikro berada pada posisi yang mendukung strategi agresif dimana fokus pembinaan harus diarahkan pada ekspansi pasar dan penguatan daya saing dalam rangka mengadapi pasar bebas. Strategi yang dapat dilakukan dalam implementasi Renstra SKPD untuk mengatasi permasalahan pemasaran usaha mikro adalah: (1) membangun jaringan kerjasama hulu-hilir dengan memberdayakan komunitas/ asosiasi UMKM; dan (2) memfasilitasi pembangunan jaringan pemasaran online terpadu berbasis komunitas.

\section{Saran}

Hasil penelitian ini memberikan beberapa rekomendasi antara lain: (1) Dinas Koperindag perlu memasukan lebih banyak aspek substantif dalam perencanaan strategis, diantaranya dengan melibatkan pelaku usaha mikro dan komunitas/asosiasi UMKM dalam rangka menyusun perencanaan yang efektif, sehingga hasil perencanaan yang dihasilkan mempunyai legitimasi yang kuat ketika dihadapkan pada proses politis dalam pembahasan di tingkat kelembagaan yang lebih tinggi; (2) Pemerintah Kota Batu perlu meningkatkan koordinasi lintas sektor antar SKPD dalam pembinaan usaha mikro antara lain melalui pembagian aspek/sisi pembinaan bagi usaha mikro dan penataan regulasi yang mendukung pertumbuhan usaha mikro dengan melibatkan seluruh stakeholder, serta penegakan hukum dalam rangka membina iklim usaha yang kondusif; (3) Dinas Koperindag perlu menyusun database UMKM yang akurat, komprehensif dan terintegrasi sebagai dasar pembinaan bagi usaha mikro; (4) Pemerintah Kota Batu perlu membangun komitmen yang kuat dalam upaya meningkatkan kesejahteraan masyarakat dari sisi pembangunan ekonomi berbasis sektor usaha mikro dengan melibatkan seluruh stakeholder dengan lebih menekankan pada promosi dan penguatan daya saing dalam rangka menyongsong era perdagangan bebas; (5) Dinas Koperindag perlu mengoptimalkan peran PLUT-KUMKM untuk membangun mindset positif pelaku usaha mikro agar lebih siap menghadapi persaingan di era perdagangan bebas; (6) Pemerintah Kota Batu perlu memperkuat kelembagaan komunitas/asosiasi UMKM misalnya dalam bentuk koperasi agar memiliki landasan hukum yang kuat dalam pembangunan kerjasama untuk memperkuat jaringan hulu dan hilir dari usaha mikro; (7) Pemerintah Kota Batu bekerjasama dengan akademisi perlu melakukan kajian terhadap kemampuan daya dukung dan keberlanjutan ketersediaan bahan baku lokal bagi usaha mikro (8) Perlu dilakukan penelitian lebih lanjut sebagai feasibility study atas strategi alternatif yang dihasilkan dari penelitian ini.

\section{UCAPAN TERIMA KASIH}

Penulis mengucapkan terima kasih yang sebesarbesarnya kepada: (1) Pimpinan dan segenap Civitas Akademik Fakultas IImu Administrasi Universitas Brawijaya; (2) Kepala Pusat Pembinaan, Pendidikan dan Pelatihan Perencana Bappenas; (3) Walikota dan segenap Jajaran Pemerintah Kota Batu; (4) Semua pihak yang telah mendukung hingga selesainya penelitian ini.

\section{DAFTAR PUSTAKA}

[1]. Utami, Ramadhilla Maghfira dan Donald Crestofel Lantu. 2014. Development Competitiveness Model for Small-Medium Enterprises among the Creative Industry in Bandung. Procedia - Social and Behavioral Sciences. 115. 305-323 melalui http:// www.sciencedirect.com/science/article/pii/ 
S1877042814019867 diakses tanggal 29 September 2014.

[2]. Kementerian Koperasi dan UKM. 2014. Perkembangan Data UMKM dan Usaha Besar. melalui http://www.depkop.go.id diakses tanggal 26 Juni 2015.

[3]. World Bank. 2001. Small and Medium Enterprise Development.

[4]. Kuncoro, Mudrajad. 2007. Ekonomika Industri Indonesia: Menuju Negara Industri Baru 2030. ANDI. Yogyakarta.

[5]. Kadarisman, Hoedhiono. 2007. Memperkuat Ekonomi Nasional Berbasis Usaha Kecil dan Menengah. Kelompok Independen Indonesia. Jakarta.

[6]. Sok, Phyra, Aron O'Cass, dan Keo Mony Sok. 2013. Achieving Superior SME Performance: Overarching Role of Marketing, Innovation, and Learning Capabilities. Australasian Marketing Journal. 2. 161-167. melalui http://www.sciencedirect.com/science/arti cle/pii/S1441358213000177 diakses tanggal 3 Juni 2015.

[7]. McFarland, Christiana dan Kathleen McConnell. 2012. Small Business Growth During a Recession: Local Policy Implications. Economic Development Quarterly. 27(2). 102-113. melalui http://edq. sagepub.com/content/early/2012/10/07/08 91242412461174 diakses tanggal 9 Oktober 2014.

[8]. Tambunan, Tulus 2008. SME Development, Economic Growth, and Government Intervention in A Developing Country: The Indonesian Story. Journal of International Entrepreneurship. 6. 147-167. melalui http://link.springer.com/article/10.1007\%2 Fs10843-008-0025-7 diakses tanggal 15 Juni 2015.

[9]. Triastuti, Maria Rosarie Harni. 2013. Menakar Kapasitas Governance Pemerin-tah Daerah Dalam Memfasilitasi Usaha Kecil dan Menengah. Jurnal Ilmu Administrasi. X(2): 186-198. melalui http://www.ejurnal.com/2014/05/menakar-kapasitasgovernance-pemerintah.html diakses tanggal 27 September 2014.

[10]. Susilo, Y. Sri. 2010. Strategi Meningkatkan Daya Saing UMKM Dalam Menghadapi Implementasi CAFTA dan MEA. Buletin Ekonomi.. 8(2.: 70-78. melalui repository. upnyk.ac.id/2437/1/sri_susilo082011juli.pdf diakses tanggal 15 Mei 2015.

[11]. Kotler, Phillip, Hermawan Kartajaya dan Iwan Setiawan. 2010. Marketing 3.0: Mulai dari
Produk ke Pelanggan ke Human Spirit. Erlangga. Jakarta.

[12]. Suryono, Agus dan Trilaksono Nugroho. 2008. Paradigma, Model, Pendekatan Pembangun-an, dan Pemberdayaan Masyarakat di Era Otonomi Daerah. Bayumedia. Malang.

[13]. Salusu, J. 2004. Pengambilan Keputusan Stratejik Untuk Organisasi Publik dan Organisasi Non-Profit. Gramedia. Jakarta.

[14]. Bryson, John M. 2005. Strategic Planning for Public and Nonprofit Organization: A Guide for Strengthening and Sustaining Organizational Achievment. Revised Edition. JoseyBass Publisher. San Francisco. Penerjemah: M. Miftahudin (2005). Perencanaan Strategis Bagi Organisasi Sosial. Pustaka Pelajar. Yogyakarta.

[15]. Riyadi dan Deddy Supriyady Bratakusumah. 2004. Perencanaan Pembangunan Daerah. Gramedia. Jakarta.

[16]. Faludi, Andreas. 1973. Planning Theory. Pergamon Press. Oxford.

[17]. Herdiansyah, Haris. 2011. Metodologi Penelitian Kualitatif untuk IImu-ilmu Sosial. Cetakan kedua. Salemba Humanika. Jakarta.

[18]. Miles, Matthew B., A. Michael Huberman dan Johnny Saldana. 2014. Qualitative Data Analysis: A Method Sourcebook. Third Edition. Sage Publication. USA.

[19]. Allison, Michael dan Jude Kaye. 2005. Strategic Planning for Nonprofit Organization. Pengantar oleh Faisal Basri (2005). Perencanaan Strategis Bagi Organisasi Nirlaba. Yayasan Obor. Jakarta.

[20]. Arsyad, Lincolin. 2004. Ekonomi Pembangunan. BPSTIE YKPN. Yogyakarta.

[21]. Kuncoro, Mudrajad. 2012. Perencanaan Daerah, Bagaimana Membangun Ekonomi Lokal, Kota dan Kawasan. Erlangga. Jakarta.

[22]. Chandra, Gregorius, Yanto Chandra dan Fandy Ciptono. 2004. Pemasaran Global: Internasionalisasi dan Internetisasi. ANDI. Yogyakarta. 